\title{
LATE PLEISTOCENE LITHIC PROCUREMENT AND GEOCHEMICAL CHARACTERIZATION OF THE CERRO KASKIO OBSIDIAN SOURCE IN SOUTH-WESTERN BOLIVIA*
}

\author{
J. M. CAPRILES $\dagger$
}

Department of Anthropology, The Pennsylvania State University, University Park, PA 16802, USA N. TRIPCEVICH

Archaeological Research Facility, University of California, Berkeley, CA 94720, USA

\author{
A. E. NIELSEN
}

Consejo Nacional de Investigaciones Científicas y Técnicas-Instituto Nacional de Antropología y Pensamiento Latinoamericano, Buenos Aires, Argentina

\section{D. GLASCOCK}

Archaeometry Laboratory, University of Missouri Research Reactor, 1513 Research Park Drive, Columbia, MO 65211, USA

\section{J. ALBARRACIN-JORDAN}

Instituto de Investigaciones Antropológicas y Arqueológicas, Universidad Mayor de San Andrés, La Paz, Bolivia and C. M. SANTORO

Instituto de Alta Investigación, Universidad de Tarapacá, Antofagasta 1520, Arica, Chile

\begin{abstract}
Primary questions regarding the foraging behaviour of the first hunter-gatherers who colonized the New World are how they found, procured and utilized high-quality raw materials for manufacturing stone tools. In this paper, we present evidence from the late Pleistocene site of Cueva Bautista in the highlands of south-western Bolivia, which demonstrates that a substantial portion of the recovered stone tool assemblage originated in Cerro Kaskio, a recently discovered obsidian source located $15 \mathrm{~km}$ south-west of the site. In addition to describing the geological and geochronological setting, we provide the first geochemical characterization of the Cerro Kaskio source by means of instrumental neutron activation analysis and energydispersive X-ray fluorescence. Supported on the technological analysis and archaeometric sourcing of the obsidian lithics found in Cueva Bautista, we discuss the nature of the procurement strategies practised by the earliest mobile hunter-gatherers who explored and colonized the Andean highlands. We conclude that opportunistic lithic resource procurement was probably an important component of the first foraging societies that explored the highland Andes.
\end{abstract}

\footnotetext{
KEYWORDS: ANDES, LITHIC PROCUREMENT, MOBILITY, OBSIDIAN, SOURCING, INAA, ED-XRF
}

\section{INTRODUCTION}

The foraging behaviour of the earliest hunter-gatherers that led to the exploration and colonization of the New World is frequently described in terms of a series of attributes, including the procurement of large game, high levels of residential mobility and the use of high-quality stone tool raw materials (Goebel et al. 2008; Meltzer 2009; Madsen 2015). The relationship between early 
human foragers (commonly referred to in North and South America as 'Palaeoindians') and the procurement of megafauna, including the potential role of humans in their extinction, is a topic that receives sustained examination (Borrero 2009; Meltzer 2015; Méndez 2015; Barnosky et al. 2016; Politis et al. 2016). Nevertheless, other factors often used to explain the rapid human dispersion across the Americas have merited less public attention but are still subject to scrutiny (Kelly and Todd 1988; Speth et al. 2013). For instance, simulation experiments have verified that high residential mobility would be compatible with high fertility rates and the rapid spread of archaeological sites throughout the Americas (Anderson and Gillam 2000; Surovell 2000; Hazelwood and Steele 2004). In this paper, we focus on the procurement of high-quality stone tool raw materials, by addressing resource exploitation strategies during the late Pleistocene human colonization of the highland Andes. To this effect, we assess evidence from Cueva Bautista, a high-elevation, short-term occupation camp recently excavated in south-western Bolivia that contains a stone tool assemblage dated between 12700 and $12100 \mathrm{cal}$ BP (Capriles et al. 2016). In addition, we describe the geological setting and geochemical composition of Cerro Kaskio, a newly discovered obsidian source situated $15 \mathrm{~km}$ from Cueva Bautista. We then use this information to discuss the likely strategies of lithic exploitation and utilization developed by the initial human foragers who explored the Andean highlands.

\section{STONE TOOL RAW MATERIAL PROCUREMENT BY LATE PLEISTOCENE HUNTER-GATHERERS}

The access and collection of stone raw materials for the manufacture of chipped stone tools by hunter-gatherers is often discussed in terms of direct or embedded procurement strategies (Binford 1979). Direct procurement consists of the specific residential or logistical movement of individuals or task groups from their residential locations to the raw material sources. Embedded procurement involves the incidental discovery and collection of raw materials as part of foraging trips motivated by other tasks such as food provisioning. In addition, an indirect procurement strategy would imply access to the required raw materials by means of exchange with other groups or intermediaries.

Archaeologists have long debated the procurement strategies favoured by Palaeoindian hunter-gatherers (Gould and Saggers 1985; Seeman 1994; Bamforth 2006; Surovell 2009; Speth et al. 2013). For human foragers exploring new territories, stone raw material procurement should depend on various factors, including the quality, availability and distribution of raw materials in known regions in relation to the uncertainty of the distribution and frequency of comparable resources in unknown areas (Kelly 1988; Kuhn 1992; Brantingham 2003). 'Highquality' raw materials can be defined as a function of their knapability, which depends on their compositional and structural homogeneity, and conchoidal fracture, as well as other properties, including nodule size, texture and so on. The distribution of high-quality raw materials is a function of geology and, therefore, could potentially be anticipated in a geographically familiar region. If known raw materials are considered to be of 'high quality', they can be mapped in by foragers who might then return to these locations regularly for logistical direct provisioning. Furthermore, depending on their distribution and availability, the use and circulation of high-quality raw materials may reflect behavioural adaptations, such as high residential mobility, but also costly signalling as key to the reproduction of social networks (Speth et al. 2013). Several case studies, from both North America and South America, suggest that Palaeoindian foragers readily procured 'high-quality' raw materials, such as agate, jasper and obsidian located hundreds of kilometres away from their residential camps, through logistical movements or exchange (Suárez 2011; Boulanger et al. 2015; Flegenheimer and Weitzel 2017). Yet, many high-quality raw materials were also procured through embedded strategies, as part of more constrained foraging 
ranges (Borrero and Franco 1997; Dillehay 2008; Franco et al. 2015). Therefore, discussion of the procurement and utilization of high-quality raw materials is important for understanding the variability associated with Palaeoindian foraging behaviour across the New World.

In addition to the acquisition of high-quality raw materials, the question of transport is significant for understanding procurement strategies and the organization of lithic technology as a whole. Transportation of complete nodules, partially reduced cores, moderately knapped bifaces or even finished artefacts, including the reliance on specialized quarry workshops, are all important correlates for differentiating direct procurement from embedded strategies. To understand the dynamics of this process, one can focus on the lithic utilization loci, but it is also important to observe the sources themselves, as well as their distribution ranges (Tripcevich and Contreras 2011; Freund 2013). In the Andes, the geological landscape is highly heterogeneous and, although specific locations with 'high-quality' raw materials are abundant, their exact location from one region to another is highly variable and potentially difficult to anticipate.

To determine the origin and distribution of lithic raw materials, researchers must adequately connect sources and artefacts. This work involves not only characterizing the elemental composition of a specific artefact but also knowing the location and geochemical composition of the range of potential sources. Advances in archaeometric techniques, primarily using instrumental neutron activation analysis (INAA), energy-dispersive X-ray fluorescence (ED-XRF) and inductively coupled plasma - mass spectrometry (ICP-MS) have facilitated this work by helping to quantitatively characterize the geochemical composition of lithic samples from sources and archaeological sites (Glascock and Neff 2003; Andrefsky 2005; Shackley 2005).

\section{OBSIDIAN SOURCES STUDIES IN THE ANDES}

One of the highest-quality lithic materials available in the Andes is obsidian. The use of obsidian has been documented in sites that range from the earliest human occupations during the late Pleistocene up to the Inca conquest (Burger et al. 1998a, 1998b, 2000; Burger and Glascock 2000; Glascock et al. 2007; Kellett et al. 2013). Research in the central Andes of Peru has helped to locate and characterize some of the most important obsidian sources in the region, including Alca, Chivay and Quispisisa (Jennings and Glascock 2002; Tripcevich 2007; Tripcevich and Contreras 2011; Tripcevich and Mackay 2011, 2012; Rademaker et al. 2013; Tripcevich, Contreras 2013). Similar work across the Argentinean and Chilean southern Andes has helped to locate and differentiate the complex landscape of sources in those regions (Seelenfreund et al. 1996; Yacobaccio et al. 2002, 2004; Barberena et al. 2011; Giesso et al. 2011; Méndez et al. 2012; Salgán et al. 2015; Cortegoso et al. 2016; Escola et al. 2016; Pintar et al. 2016). Yet in intermediate regions, such as the Bolivian Andes, the location of many sources remains unknown and many of the currently known sources were poorly documented until recently (Brooks et al. 1997; Giesso 2003; Seelenfreund et al. 2010a, 2010b; Glascock and Giesso 2012; Williams et al. 2012). This pattern is exacerbated by the lack of research about the periods that precede the development of agricultural complex societies, which is the focus of most research within the region.

The Altiplano-Puna volcanic complex of northern Chile, south-western Bolivia and north-west Argentina is a region dominated by snow-capped volcanoes, extinct calderas and large ignimbrites formed by arc magmatism with the tectonic uplift of the Altiplano (Fig. 1) (De Silva 1989; Allmendinger et al. 1997; Soler et al. 2007). A period of increased mafic volcanism occurred during the late Miocene to early Pliocene (11-3 Mya), when most of the existing landscape was formed. A series of caldera eruption pulses during this period included the formation of at least 300 different ignimbrite outcrops in 60 units (Salisbury et al. 2010). The 


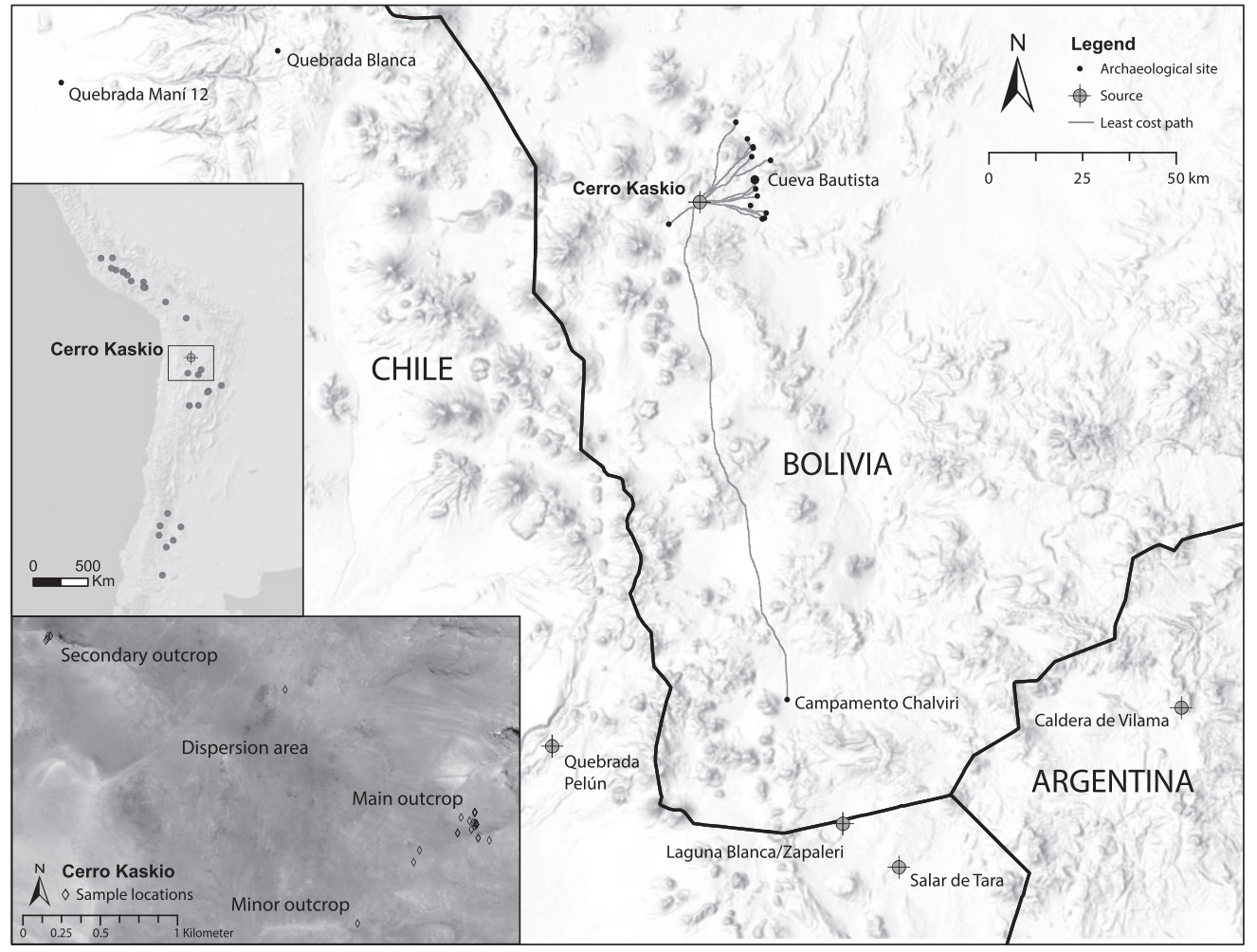

Figure 1 The Altiplano-Puna volcanic complex, showing the location of Cueva Bautista and Cerro Kaskio, as well as other archaeological sites and sources mentioned in the text. The insets show the distribution of obsidian sources between the central and southern Andes and Cerro Kaskio's obsidian outcrops and dispersion area.

composition of these outcrops is dominantly dacitic, and a recent study involving high-precision ${ }^{40} \mathrm{Ar} /{ }^{39} \mathrm{Ar}$ geochronology determined that at least three different large-scale volcanic pulses have occurred in the past 10 million years, determining the geological configuration of the region (Salisbury et al. 2010). The formation of this landscape also involved a few important obsidian outcrops, most of which remain unstudied or poorly documented (Yacobaccio et al. 2004; Seelenfreund et al. 2010a). Human foragers initially colonized these highlands in the late Pleistocene $(c .13000 \mathrm{cal} \mathrm{BP})$, during a wet climatic pulse that would have favoured ecological productivity (Núñez et al. 2002; Grosjean et al. 2005; Placzek et al. 2013; Santoro et al. 2017).

\section{MATERIALS AND METHODS}

The Cueva Bautista dry rock shelter is approximately $70 \mathrm{~m}$ to the west and $20 \mathrm{~m}$ above the current shore of the Sora River, at 3930 m above sea level (a.s.l.) in the Lípez highlands of southwestern Bolivia (Albarracin-Jordan and Capriles 2011). We recently reported the stratigraphic, chronological and contextual associations of the site's earliest occupation, including radiocarbon dating and artefact analyses (Capriles et al. 2016). Based on the presence of small hearths and relatively small faunal and lithic assemblages, we argued that the rock shelter was initially used as a temporary camp by highly mobile human foragers. Eight radiocarbon dates place this 
occupation between 12700 and $12100 \mathrm{cal}$ BP, which is roughly contemporaneous with the second pulse of the central Andean pluvial event that involved increased humidity in the region. These conditions deteriorated during the mostly arid, Early and Middle Holocene (Placzek et al. 2006), when the site was not occupied. Subsequent reoccupations occurred when humid conditions returned to the region at the onset of the Late Holocene (c.4500 cal BP).

To assess the procurement strategy of high-quality raw materials by early human foragers during the late Pleistocene, we analysed the morphological and technological attributes of all the lithic remains recovered in Cueva Bautista. In addition, we conducted an archaeological survey within the boundaries of the Sora River valley, identifying other rock shelters and open-air sites (Albarracin-Jordan et al. 2014). More importantly, we identified a new obsidian source, Cerro Kaskio. We carried out surface reconnaissance and collected georeferenced samples of obsidian specimens at the source and its immediate vicinity to maximize the heterogeneity of our sample and intra-source geochemical variability (Shackley 1998). Samples were collected and analysed by means of INAA and subjected to both short and long counts, using standard procedures (Glascock et al. 2007). We also analysed samples, using two nearly identical ED-XRF portable devices (one owned by MURR and the other by the University of California, Berkeley's Archaeological Research Facility). Both ED-XRF instruments are Bruker Tracer III-SD, which were run using the manufacturer's specifications for obsidian and supplementary calibration procedures (Craig et al. 2007; Glascock 2010; Ebert et al. 2015). More specifically, all samples were analysed between 180 and $200 \mathrm{~s}$ with the green filter and sediment settings, using $40 \mathrm{keV}$ at $40 \mu \mathrm{A}$. The ED-XRF spectral results were then calibrated through a correction developed with reference to chemical concentrations derived from multiple analysis methods (Glascock and Ferguson 2012). Both instruments are also part of a larger inter-instrument control study. In addition, we selected one Cerro Kaskio source sample to date the origin of the obsidian flow and comparative samples from other two sources (Salar de Tara and Quebrada Pelún) by means of ${ }^{40} \mathrm{~K} /{ }^{39} \mathrm{Ar}$ dating, the samples being analysed at the isotopic geology laboratory of Chile's Servicio Nacional de Geología y Minería.

\section{RESULTS}

\section{Technological organization and obsidian utilization in Cueva Bautista}

The human occupation of Cueva Bautista can be roughly divided in three phases: late Pleistocene, Archaic and Agropastoralist. The late Pleistocene occupation (12 700-12 100 cal BP), which is the focus of our study, corresponds to the initial and most significant hunter-gatherer use of the site. Contextual evidence suggests that it was a temporary and, most probably, logistical foraging camp (Capriles et al. 2016). The Archaic occupation (5500-3500 cal BP) corresponds to the return of hunter-gatherers during the onset of the Late Holocene, following a long occupational hiatus, which involved the use of the rock shelter for sporadic residence. Finally, between the Formative period and the Spanish conquest, Agropastoralist groups (3500-400 cal BP) sporadically carried out a series of mainly funerary and other ritual and economic activities at the site.

We carried out a morphological and technological attribute analysis of the entire lithic assemblage of Cueva Bautista, which consists of roughly 439 stone tools and debitage (Table 1). The late Pleistocene assemblage is dominated by stone tools and debitage manufactured with obsidian $(56.5 \%)$. Other important raw materials include a silcrete-like lustrous brown chert, jasper and other less frequent igneous and sedimentary rocks. Obsidian use decreases between the late 
Table 1 Raw material by occupation phase at Cueva Bautista

\begin{tabular}{|c|c|c|c|c|c|c|c|c|}
\hline Raw material & Late Pleistocene & $\%$ & Archaic & $\%$ & Agropastoralist & $\%$ & Total & $\%$ \\
\hline Obsidian & 217 & 56.5 & 6 & 21.4 & 6 & 22.2 & 229 & 52.2 \\
\hline Brown chert & 139 & 36.2 & 8 & 28.6 & 1 & 3.7 & 148 & 33.7 \\
\hline Grey chert & 1 & 0.3 & 10 & 35.7 & 9 & 33.3 & 20 & 4.6 \\
\hline Jasper & 15 & 3.9 & 2 & 7.1 & 2 & 7.4 & 19 & 4.3 \\
\hline White chert & 6 & 1.6 & 1 & 3.6 & 6 & 22.2 & 13 & 3.0 \\
\hline Basalt & 3 & 0.8 & & & 1 & 3.7 & 4 & 0.9 \\
\hline Sandstone & & & 1 & 3.6 & 2 & 7.4 & 3 & 0.7 \\
\hline Chalcedony & 2 & 0.5 & & & & & 2 & 0.5 \\
\hline Andesite & 1 & 0.3 & & & & & 1 & 0.2 \\
\hline Total & 384 & 100 & 28 & 100 & 27 & 100 & 439 & 100 \\
\hline ED-XRF obsidian & 61 & 28.1 & 5 & 83.3 & 6 & 100 & 72 & 31.4 \\
\hline
\end{tabular}

Pleistocene occupation and the later reoccupations of the site, but it remains important $(>20 \%)$. Moreover, the proportion and dominance of high-quality raw materials decreases through time, as coarser grey and white cherts become increasingly common during the late Archaic and Agropastoralist periods.

The late Pleistocene obsidian tools include three bifacial retouched edges, a notch tool and a backed flake with a retouched edge, all of which might have originated in larger instruments (Table 2). In addition, abundant flakes, bifacial thinning flakes, blades, retouch flakes and shatter fragments suggest that obsidian reduction and maintenance activities were carried out at the site. The absence of cores, the low frequency of cortex $(N=14)$ and cortical platforms $(N=7)$, and the abundant retouch debitage suggest that maintenance was more important than manufacturing at the site. In fact, most flakes, including small retouch flakes, are complete, and both medial and distal ends with undetermined platform and terminations types are relatively infrequent. The size range of flakes and retouch flakes is also quite narrow (maximum length $\bar{x}=12.7 \pm 11.2 \mathrm{~mm} 1 \sigma$ ) and, therefore, is consistent with secondary reduction, maintenance activities, a reliance on small cores or a combination of the above (Fig. 2). The Archaic and Agropastoralist period assemblages are smaller and include cores and an end scraper, consistent with other changes in the site's use and occupation intensity.

\section{Cerro Kaskio}

Cerro Kaskio is located $15 \mathrm{~km}$ south-west of Cueva Bautista and approximately $3.6 \mathrm{~h}$ away, following a least-cost path based on Tobler's hiking function implemented in ArcGIS's path distance tool on a SRTM 1 arc second $(\sim 30 \mathrm{~m})$ digital elevation model (Fig. 1). Cerro Kaskio is part of a volcanic ignimbrite mountain within an arid and rocky landscape dominated by grasslands that are interspersed by a few shrubs and small patches of keñua trees (Polylepis tarapacana). Presently occupied as a nocturnal sleeping territory of wild vicuña herds, which graze during the day in the nearby wetlands, its slopes are covered by hundreds of dung piles. The obsidian source of Cerro Kaskio was independently identified by Nielsen and Capriles while working on different projects. Nielsen was initially taken to the source by herders of the Copacabana community, whereas Capriles was taken there by herders from Alota. Copacabana and Alota are adjacent Quechua-speaking camelid pastoralist communities that share similar 
Table 2 Obsidian stone tools and debitage from the late Pleistocene human occupation of Cueva Bautista organized by lithic category and flake termination in relation to platform type

\begin{tabular}{|c|c|c|c|c|c|c|c|}
\hline \multirow{2}{*}{$\begin{array}{l}\text { Lithic category and flake } \\
\text { termination }\end{array}$} & \multicolumn{7}{|c|}{ Platform type } \\
\hline & Cortical & Flat & Complex & Abraded & Broken & Undetermined & Total \\
\hline \multicolumn{8}{|l|}{ Tools and cores } \\
\hline \multicolumn{8}{|l|}{ Bifacial retouched edge } \\
\hline Feathered & 1 & & & & & & 1 \\
\hline Undetermined & & & & & & 2 & 2 \\
\hline \multicolumn{8}{|l|}{ Notch tool } \\
\hline Undetermined & & & & & & 1 & 1 \\
\hline \multicolumn{8}{|l|}{ Flake with retouched edge } \\
\hline Undetermined & & & & & & 1 & 1 \\
\hline \multicolumn{8}{|l|}{ Debitage } \\
\hline \multicolumn{8}{|l|}{ Flake } \\
\hline Feathered & & 4 & 5 & 1 & 23 & 4 & 37 \\
\hline Hinged & & & & & 1 & & 1 \\
\hline Stepped & 3 & 5 & 5 & & 25 & 6 & 44 \\
\hline Undetermined & 1 & & & & 1 & & 2 \\
\hline \multicolumn{8}{|l|}{ Biface thinning flake } \\
\hline Feathered & & & 1 & & 2 & & 3 \\
\hline Stepped & & & 1 & & & & 1 \\
\hline \multicolumn{8}{|l|}{ Blade } \\
\hline Feathered & 1 & & & & & & 1 \\
\hline Stepped & & 1 & & & & & 1 \\
\hline \multicolumn{8}{|l|}{ Retouch flake } \\
\hline Feathered & 1 & 13 & 10 & 2 & 46 & 3 & 75 \\
\hline Hinged & & & 1 & & 2 & & 3 \\
\hline Stepped & & 6 & 5 & & 21 & 2 & 34 \\
\hline Undetermined & & & & & 1 & 1 & 2 \\
\hline \multicolumn{8}{|l|}{ Shatter fragment } \\
\hline Undetermined & & & & & 3 & 3 & 6 \\
\hline Total & 7 & 29 & 28 & 3 & 125 & 25 & 217 \\
\hline
\end{tabular}

patterns of subsistence and mobility (Tomka 2001a, 2001b). Although herders today have no use for obsidian, they remember using it in the past for castrating llamas and for ritual. Local inhabitants know the area as Cerro Kaskio (or Kasquiu), but the ignimbrite lobe where the source is located is specifically known as Kansor Kharka.

Fieldwork at Cerro Kaskio involved systematic exploration and collection of obsidian nodules from the surface and exposed profiles. The source comprises a main outcrop, secondary and minor outcrops, and a general dispersion area. The main outcrop is situated at approximately $4320 \mathrm{~m}$ a.s.1., measures about $20 \mathrm{~m}$ in diameter and contains a narrow $2 \mathrm{~m}$ deep extraction pit from recent mining efforts. In the profile of the pit, the obsidian outcrop is observable as a disarticulated flow of prismatic structure intersected by spherical tuff fragments and pumice. The nodules are mostly small $(\sim 5 \mathrm{~cm}$ in diameter) and subangular, but many are larger $(>10 \mathrm{~cm})$ and subrounded. The Alota herders mentioned that although a depression was noted at the site, the pit was enlarged around 15 years ago, when a group of them collected a truckload of the material for sale in Uyuni, thinking that it might have commercial value. Given that the material did not sell as expected, they did not return to the site. 


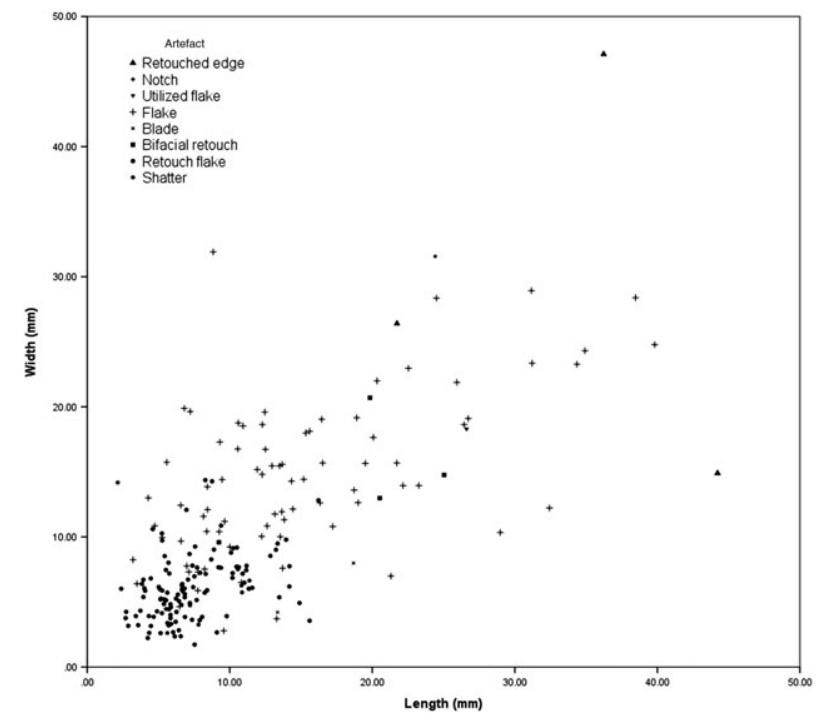

Figure 2 The size range of obsidian tools and debitage from the late Pleistocene human occupation at Cueva Bautista.

A secondary outcrop is situated approximately $1 \mathrm{~km}$ to the south-west and upslope (4347 $\mathrm{m} \mathrm{a}$. s.1.) from the main source. This second and intact outcrop can be mistaken as a vicuña dung pile, which suggests that others like it might be present elsewhere in the mountain. Unlike the first extraction pit, this second outcrop measured roughly $10 \mathrm{~m}$ in diameter and included evidence of a shallow depression containing mostly small subangular nodules $(\sim 8 \mathrm{~cm})$. A few small flakes and blades interspersed with unmodified nodules in the surface of outcrop suggest that evidence of primary extraction is still observable in situ.

The general secondary dispersion of the Cerro Kaskio obsidian spans roughly $10 \mathrm{~km}^{2}$, mostly towards the south-west and down the slope of Kansor Kharka. In addition to nodules of various sizes, within this dispersion we occasionally identified cores with a few extractions, flakes and retouched flakes. On the terraces that flank the temporary drainage that flows westward from Cerro Kaskio there are several sites with not only obsidian debris, but tools, other lithic materials (basalt, chert), and even some ceramics, attesting to the long-term use of this source. However, we did not observe the existence of any specialized workshop or specialized activity areas. The Cerro Kaskio obsidian is mostly translucent black with grey and dark brown hues, and can include small white spherulites. Despite the presence of spherulites, the raw material is adequate for making small sharp flake tools and blades.

\section{Geochemical composition and ${ }^{40} \mathrm{~K}^{\beta 9} \mathrm{Ar}$ dating}

To characterize the geochemical composition of the Cerro Kaskio obsidian, eight samples initially collected by Nielsen were complemented by 20 new georeferenced samples at MURR for both INAA and ED-XRF. In addition, we also analysed 15 additional source samples with UCB's ED-XRF instrument. Together, these samples comprise the full range of the currently known spatial and stratigraphic extent of the source. The resulting data from our Cerro Kaskio reference sample consist of 28 INAA specimen readings (Table S1) and 43 ED-XRF specimen readings (Table S2). These techniques provided consistent results for five replicated elements (Fe, $\mathrm{Rb}, \mathrm{Zn}, \mathrm{Zr}$ and $\mathrm{Th}$ ). We did not observe significant chemical differences among specimens 
collected from different locations within the source, including the second outcrop and secondary dispersions, suggesting a mostly homogenous composition (Table 3). As measured by both INAA and ED-XRF, obsidian from Cerro Kaskio is compositionally distinct from other known Altiplano-Puna volcanic complex sources, including Laguna Blanca/Zapaleri, Caldera Vilama, Salar de Tara and Quebrada Pelún (Figs 3 (a) and 3 (b)) (De Souza et al. 2002; Yacobaccio et al. 2002, 2004; Seelenfreund et al. 2010a).

The ${ }^{40} \mathrm{~K} /{ }^{39} \mathrm{Ar}$ dating of an obsidian sample from Cerro Kaskio produced a date of $5.7 \pm 0.4$ Mya $(2 \sigma)$ (P976). A previous ${ }^{40} \mathrm{~K} /{ }^{39}$ Ar date on andesite hornblende dated the formation of Cerro Kaskio to 13.8 \pm 1.0 Mya (AL-56) (Pacheco and Ramírez 1997). Nevertheless, the new date of the actual obsidian flow is consistent with a more recent study that places Cerro Kaskio within the Chuhuilla caldera volcanic phase, which during the Pliocene produced the immediately surrounding ignimbrites (Salisbury et al. 2010). According to the regional geochronology, Cueva Bautista possibly formed during the same volcanic pulse (Pacheco and Ramírez 1997). As part

Table 3 A summary of MURR's INAA and ED-XRF results for Cerro Kaskio's obsidian, including sample size, mean and standard deviation: elements in ppm unless otherwise specified

\begin{tabular}{lcc}
\hline \hline & $I N A A$ & \\
& $n=28$ & $n=28$ \\
\hline Element & $\bar{x} \pm 1 \sigma$ & $\bar{x} \pm 1 \sigma$ \\
$\mathrm{Fe}(\%)$ & $0.61 \pm 0.02$ & $0.65 \pm 0.02$ \\
$\mathrm{Rb}$ & $207.9 \pm 2$ & $209.9 \pm 6$ \\
$\mathrm{Zn}$ & $53.5 \pm 1$ & $63.6 \pm 15$ \\
$\mathrm{Zr}$ & $154 \pm 6.27$ & $81.5 \pm 5.34$ \\
$\mathrm{Sr}$ & n.d. & $1.9 \pm 0.97$ \\
$\mathrm{Y}$ & n.d. & $24.3 \pm 2.66$ \\
$\mathrm{Nb}$ & n.d. & $17.8 \pm 1.43$ \\
$\mathrm{Th}$ & $18.5 \pm 0.3$ & \\
$\mathrm{Na}(\%)$ & $2.95 \pm 0.04$ & \\
$\mathrm{Al}(\%)$ & $6.57 \pm 0.25$ & \\
$\mathrm{Cl}$ & $588 \pm 56$ & \\
$\mathrm{~K}(\%)$ & $3.93 \pm 0.2$ & \\
$\mathrm{Sc}$ & $3.66 \pm 0.06$ & \\
$\mathrm{Mn}$ & $582 \pm 8$ & \\
$\mathrm{Co}$ & $0.03 \pm 0.01$ & \\
$\mathrm{Sb}$ & $0.72 \pm 0.02$ & \\
$\mathrm{Cs}$ & $11.6 \pm 0.16$ & \\
$\mathrm{Ba}$ & $52 \pm 10.88$ & \\
$\mathrm{La}$ & $19 \pm 0.46$ & \\
$\mathrm{Ce}$ & $45.6 \pm 1.17$ & \\
$\mathrm{Nd}$ & $21.3 \pm 1.2$ & \\
$\mathrm{Sm}$ & $5.59 \pm 0.1$ & \\
$\mathrm{Eu}$ & $0.23 \pm 0.01$ & \\
$\mathrm{~Tb}$ & $0.77 \pm 0.03$ & \\
$\mathrm{Dy}$ & $4.76 \pm 0.38$ & \\
$\mathrm{Yb}$ & $2.66 \pm 0.04$ & \\
$\mathrm{Lu}$ & $0.63 \pm 0.01$ & \\
$\mathrm{Hf}$ & $3.96 \pm 0.13$ & \\
$\mathrm{Ta}$ & $1.83 \pm 0.03$ & \\
$\mathrm{U}$ & $9.9 \pm 0.2$ & \\
\hline \hline & & \\
\hline
\end{tabular}



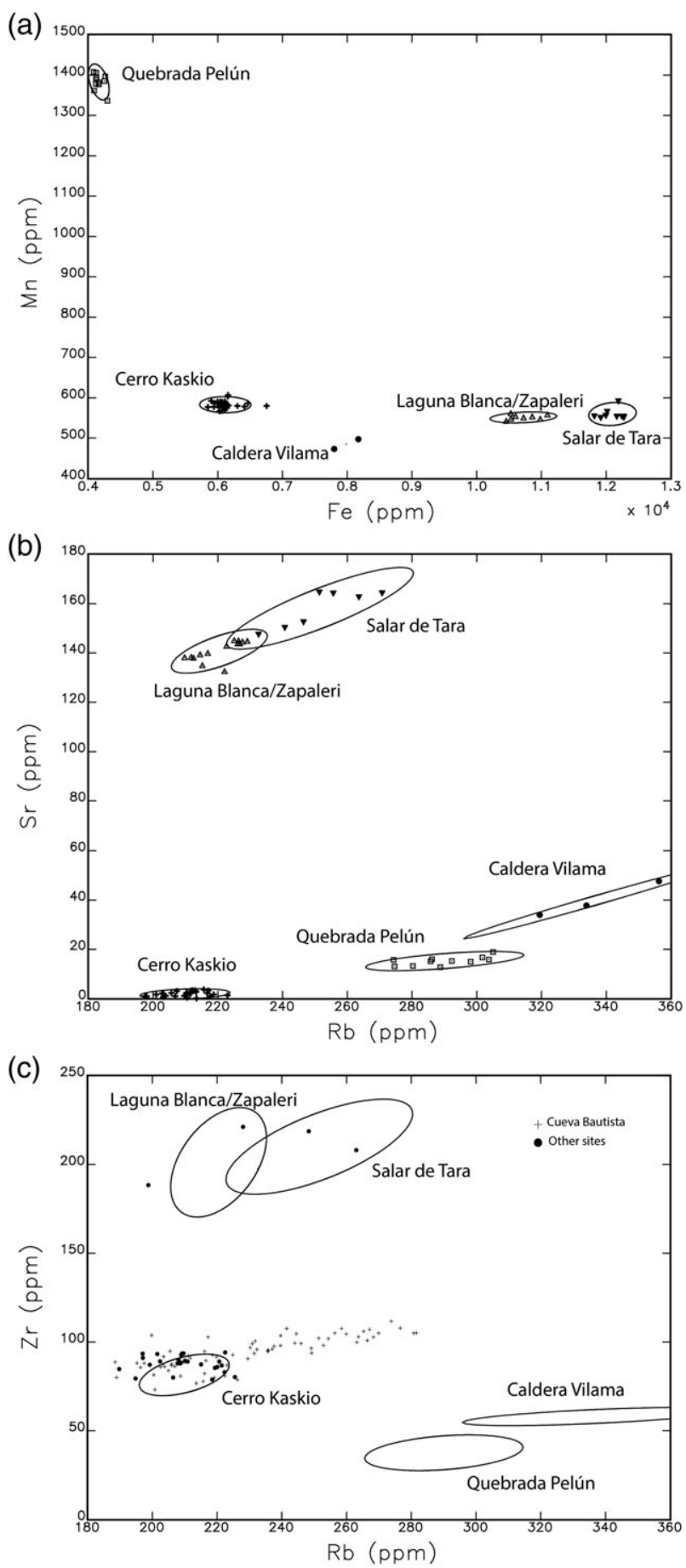

Figure 3 Scatterplots showing the elemental composition of the obsidian from Cerro Kaskio and other sources, including 95\% confidence intervals, by both (a) INAA and (b) ED-XRF, as well as (c) ED-XRF analysis of obsidian lithics from Cueva Bautista and other archaeological sites in relation to these same sources. 
of this study, we also dated a sample from Salar de Tara, which yielded a date of $2.5 \pm 0.9$ Mya (P977), and a sample of Quebrada Pelún, which provided a date of $1.5 \pm 0.4$ Mya (P945). These much younger flows strongly differ from Laguna Blanca/Zapaleri, which had been previously dated to $9.6 \pm 0.3 \mathrm{Mya}$, using the same technique (Yacobaccio et al. 2004). Together, these results suggest that all the known obsidian sources of the Chilean-Bolivian-Argentinean Altiplano-Puna volcanic complex date to different episodes of igneous plutonic activity.

\section{Geochemical sourcing of archaeological stone tools}

Given that the majority of Cueva Bautista's lithic assemblage consists of obsidian (52.2\%), we analysed 72 specimens, using ED-XRF, which is equivalent to $31.4 \%$ of the total obsidian fraction. An initial sample of 13 specimens from Cueva Bautista were run at MURR and we analysed 67 samples with UCB's instrument. Eight specimens were analysed with both instruments and produced comparable results. The obsidian sample analysed from Cueva Bautista includes every stone tool and core and a large proportion of the debitage. The majority of the analysed specimens correspond to the late Pleistocene occupation $(N=61)$, but specimens from the Late Holocene Archaic $(N=5)$ and Agropastoralist $(N=6)$ occupations of the site were also analysed (see Table S2). The remaining specimens were not analysed due to their small size: they correspond to retouch flakes, medial and distal ends of flakes, and shatter fragments that otherwise have the same colour and other physical properties that characterize the larger analysed specimens. Most of the analysed items correspond to either artefacts or flakes with platforms to avoid duplicates.

The analysis shows that all the obsidian specimens from Cueva Bautista were manufactured from Cerro Kaskio's source (Fig. 3 (c)). Many of the archaeological specimens, however, contain elemental chemistry outside of the recommended values for Cerro Kaskio, with strontium and zirconium. The anomalous results could be the consequence of analysing some very small and thin specimens (Frahm 2016). Alternatively, it is possible that these materials originated in a still undetermined outcrop in the vicinity of Cerro Kaskio, or that we did not capture the full range of variability associated with the geochemical composition of Cerro Kaskio when we sampled it.

All of the obsidian samples from the other 13 archaeological sites situated within a $25 \mathrm{~km}$ radius of Cerro Kaskio originated at this source with the exception of three samples that came from Agropastoralist contexts (Fig. 3 (c)). The exceptions include a knife found during excavations at Cueva del Chileno (a rock shelter located about $2.3 \mathrm{~km}$ south of Cueva Bautista), possibly originating from Salar de Tara. At Cueva del Chileno, four other obsidian samples-including a prismatic microblade core dated to the late Archaic (Albarracin-Jordan et al. 2014)—were sourced to Cerro Kaskio. A rock shelter (SA06) located near San Agustín, some 16 km from Cueva Bautista, included a small projectile point that originated at Caldera Vilama, but also a flake from Cerro Kaskio. Finally, Chullpas Milluni, a burial site dated to c.700-500 cal BP (Morales et al. 2013), contained a core from an unknown source.

Only one obsidian sample of this type has been identified at sites greater than a day's walk from the geological source. This was a Cerro Kaskio obsidian flake found at Campamento Chalviri (see Fig. 1). This location is situated on the southern shore of Laguna Chalviri and consists of a sizeable multi-component site used as a llama caravan encampment during the Agropastoralist period and possibly as a hunting camp during earlier periods (Nielsen et al. 2000). Campamento Chalviri is located approximately $134 \mathrm{~km}$ south of Cerro Kaskio (or approximately $30 \mathrm{~h}$ away, according to Tobler's hiking function). Nevertheless, the high consistency of the obsidian found at Cerro Kaskio makes us believe that there was a more generalized use of this 
source throughout the region, and that more sites with stone tools made of this material will be identified in the future.

As part of this study, we also analysed the only obsidian flake found during fieldwork at the site of Quebrada Maní 12 (QM12), located in the hyper-arid core of the Atacama Desert, which is roughly contemporary with the occupation of Cueva Bautista, and possibly the nearest presently known late Pleistocene site (Latorre et al. 2013). The geochemical signature of this specimen does not correspond to that of Cerro Kaskio or to any other presently known obsidian source. Another flake studied within our research sample includes a flake from Quebrada Blanca, a high-elevation site dated to the Early Holocene (Osorio et al. 2017), and which possibly corresponds to Salar de Tara, situated $270 \mathrm{~km}$ from the site and farther away than Cerro Kaskio.

\section{DISCUSSION}

The archaeometric analyses of obsidian samples from Cerro Kaskio and of tools and debitage from Cueva Bautista provide new insights regarding the organization of lithic technology among the first foragers who explored the southern Altiplano. First, our data support the view that early human foragers encountered high-quality raw materials and used them effectively. Cerro Kaskio was the sole obsidian source used at Cueva Bautista and the most important high-quality raw material discarded at the site. This pattern is stronger for the late Pleistocene occupation of the site, when obsidian accounted for more than half of the stone tool assemblage. Second, our technological analysis reveals that Cueva Bautista's obsidian tools consisted mostly of complete tools or partially reduced bifaces. Cores were rarely brought to the site. Several technological attributes suggest that the activities carried out in this rock shelter involved mainly the maintenance of tools and secondary reduction. On the other hand, the absence of formal workshops and the minute evidence of initial reduction activities at Cerro Kaskio suggest relatively rapid and selective procurement of obsidian nodules and flakes. All these attributes are typically associated with an embedded procurement strategy.

The best obsidian nodules from Cerro Kaskio, visible on the surface, are small ( $\sim 10 \mathrm{~cm}$ long) and subrounded, with a thin cortex. Despite the presence of some brittle nodules, this material is of relatively high quality. Obsidian nodules are distributed across approximately $10 \mathrm{~km}^{2}$. Individual outcrops tend to be no larger than $100 \mathrm{~m}^{2}$, where nodules were gathered and possibly flakes and blades were manufactured. It is unclear how early foragers managed to find Cerro Kaskio in the first place, given the hostile conditions associated with its high altitude, the small area covered by the obsidian outcrops and the small size of the nodules. In the context of an embedded procurement strategy, it is possible that mobile foragers, pursuing vicunas and guanacos, followed these animals to their high sleeping territories and ran across the low-density dispersion of obsidian. As they looked for the probable provenience of the nodules upslope, they may have found the main outcrops. Alternatively, foragers could have ventured into the high slopes of Kansor Kharka in search of keñua trees, which in this barren environment are the only source of wood, an important resource used not only for fuel but also for the manufacture of various utensils. In either case, the initial finding and opportunistic exploitation of the source could have led to subsequent visits, as part of foraging excursions and occasional special-purpose direct procurement (Binford 1979; Nelson 1991; Duke and Steele 2010). This interpretation is also consistent with the short-term and possibly logistical use of Cueva Bautista (Capriles et al. 2016).

The analyses of obsidian samples taken from sites at different distances from Cerro Kaskio and dating to different periods reveal some preliminary trends regarding the circulation of this raw material and its changes over time. The results of our analysis show that 26 of 29 items made of 
obsidian - from 13 out of 14 sites located within a $25 \mathrm{~km}$ radius of Cerro Kaskio-belonged to this source, which strengthens our argument concerning the sustained importance of this resource at the local scale. Moreover, given that the three specimens that came from other sources were taken from Agropastoralist contexts and that two of these correspond to sources situated over $200 \mathrm{~km}$ away (Salar de Tara and Caldera Vilama), it is likely that their circulation was facilitated by the increased inter-regional interaction and exchange cycles (Nielsen 2004; Nielsen et al. 2010; Yacobaccio 2012). Conversely, the finding of Cerro Kaskio obsidian some $134 \mathrm{~km}$ to the south, at Campamento Chalviri, might have been a consequence of similar indirect procurement routes. Other early foraging settlements situated farther away from Cerro Kaskio do not include this source's obsidian. Instead, tool manufacture at these sites probably relied mostly on locally available cherts, such as at Quebrada Maní 12, and the basalt that was used at Quebrada Blanca.

\section{CONCLUSIONS}

We have assessed the technological and geochemical composition of the obsidian from Cueva Bautista to understand the pattern associated with the procurement of high-quality stone tool raw materials by early human foragers in the highland Andes. The combination of surface reconnaissance and archaeometric sourcing by means of INAA and ED-XRF verified that Cerro Kaskio, a source situated $15 \mathrm{~km}$ from the rock shelter, was the only source of obsidian used at the site. The technological analysis suggests that most of the activities that were carried out at Cueva Bautista consisted of stone tool utilization and maintenance, but not manufacture. The field assessment of Cerro Kaskio suggests that no specialized reduction activities were carried out in its vicinity. The observed pattern is consistent with foraging strategies that emphasize the collection of small nodules and the partial reduction of cores into bifaces and flakes prior to transport, signalling technological provisioning of individuals as opposed to places (Kuhn 1992). Together, the archaeological evidence seems to support the hypothesis that early human foragers engaged in complementary embedded and logistical strategies of lithic high-quality direct resource procurement. Given that few early human foraging sites have been the focus of detailed studies regarding raw material utilization, it is difficult, at present, to generalize about the pattern observed in Cueva Bautista. Nevertheless, the utilization of localized high-quality raw materials from initial exploratory phases also supports the view that opportunistic procurement was among the behavioural foraging strategies engaged by rapidly expanding late Pleistocene hunter-gatherers.

\section{ACKNOWLEDGMENTS}

We would like to thank Zacarías Achá, Sergio Bautista, Juan Huanca, Carlos Capriles, Gabriel Capriles, Javier Cornejo, Wilfredo Faundes, Eliana Flores Bedregal, Alejandra Domic, Martin Giesso, Steven Goldstein, Katherine Herrera, Doug Kennett, Claudio Latorre, Umberto Lombardo, Daniela Osorio, Darwin Palomino, Carlos Revilla and Paula Ugalde for their help during different parts of this study. Fieldwork and export permits for our research were granted by the Bolivian Ministry of Cultures and Tourism and the Chilean Consejo Nacional de Monumentos. We acknowledge support from the National Geographic Society Committee for Research and Exploration Grant 8742-10, the Geo-Eye Foundation, CONICYT PCI Project PII20150081, FONDECYT 3140008, 1160744, and CONICYT PIA Anillo Project SOC1405. The archaeometric analyses at the University of Missouri were supported in part by the National Science Foundation Grant 1415403. 


\section{REFERENCES}

Albarracin-Jordan, J., and Capriles, J. M., 2011, The Paleoamerican occupation of Cueva Bautista: late Pleistocene human evidence from the Bolivian highlands, Current Research in the Pleistocene, 28, 95-8.

Albarracin-Jordan, J., Capriles, J. M., and Miller, M. J., 2014, Transformations in ritual practice and social interaction on the Tiwanaku periphery, Antiquity, 88(341), 851-62.

Allmendinger, R. W., Jordan, T. E., Kay, S. M., and Isacks, B. L., 1997, The evolution of the Altiplano-Puna plateau of the Central Andes, Annual Review of Earth and Planetary Sciences, 25(1), 139-74.

Anderson, D. G., and Gillam, J. C., 2000, Paleoindian colonization of the Americas: implications from an examination of physiography, demography, and artifact distribution, American Antiquity, 65(1), 43-66.

Andrefsky, W., 2005, Lithics: macroscopic approaches to analysis, Cambridge University Press, Cambridge.

Bamforth, D. B., 2006, The Windy Ridge quartzite quarry: hunter-gatherer mining and hunter-gatherer land use on the North American continental divide, World Archaeology, 38(3), 511-27.

Barberena, R., Hajduk, A., Gil, A. F., Neme, G. A., Durán, V., Glascock, M. D., Giesso, M., Borrazzo, K., de la Paz Pompei, M., Laura Salgán, M., Cortegoso, V., Villarosa, G., and Rughini, A. A., 2011, Obsidian in the southcentral Andes: geological, geochemical, and archaeological assessment of north Patagonian sources (Argentina), Quaternary International, 245(1), 25-36.

Barnosky, A. D., Lindsey, E. L., Villavicencio, N. A., Bostelmann, E., Hadly, E. A., Wanket, J., and Marshall, C. R., 2016, Variable impact of late-Quaternary megafaunal extinction in causing ecological state shifts in North and South America, Proceedings of the National Academy of Sciences, 113(4), 856-61.

Binford, L. R., 1979, Organization and formation processes: looking at curated technologies, Journal of Anthropological Research, 35(3), 255-73.

Borrero, L. A., 2009, The elusive evidence: the archaeological record of the South American extinct megafauna, in American megafaunal extinctions at the end of the Pleistocene (ed. G. Haynes), 145-68, Springer, New York.

Borrero, L. A., and Franco, N. V., 1997, Early Patagonian hunter-gatherers: subsistence and technology, Journal of Anthropological Research, 53(2), 219-39.

Boulanger, M. T., Buchanan, B., O’Brien, M. J., Redmond, B. G., Glascock, M. D., and Eren, M. I., 2015, Neutron activation analysis of 12,900-year-old stone artifacts confirms 450-510+ km Clovis tool-stone acquisition at Paleo Crossing (33ME274), northeast Ohio, U.S.A, Journal of Archaeological Science, 53, 550-8.

Brantingham, P. J., 2003, A neutral model of stone raw material procurement, American Antiquity, 68(3), 487-509.

Brooks, S. O., Glascock, M. D., and Giesso, M., 1997, Source of volcanic glass for ancient Andean tools, Nature, 376, 449-50.

Burger, R. L., and Glascock, M. D., 2000, Locating the Quispisisa obsidian source in the Department of Ayacucho, Peru, Latin American Antiquity, 11(3), 258-68.

Burger, R. L., Asaro, F., Salas, G., and Stross, F., 1998a, The Chivay obsidian source and the geological origin of Titicaca Basin type obsidian artifacts, Andean Past, 5, 203-23.

Burger, R. L., Asaro, F., Trawick, P. B., and Stross, F., 1998b, The Alca obsidian source: the origin of raw material for Cuzco type obsidian artifacts, Andean Past, 5, 185-202.

Burger, R. L., Mohr-Chávez, K. L., and Chávez, S. J., 2000, Through the glass darkly: prehispanic obsidian procurement and exchange in southern Peru and northern Bolivia, Journal of World Prehistory, 14(3), 267-362.

Capriles, J. M., Albarracin-Jordan, J., Lombardo, U., Osorio, D., Maley, B., Goldstein, S. T., Herrera, K. A., Glascock, M. D., Domic, A. I., Veit, H., and Santoro, C. M., 2016, High-altitude adaptation and late Pleistocene foraging in the Bolivian Andes, Journal of Archaeological Science: Reports, 6, 463-74.

Cortegoso, V., Barberena, R., Durán, V., and Lucero, G., 2016, Geographic vectors of human mobility in the Andes (34$36^{\circ} \mathrm{S}$ ): comparative analysis of 'minor' obsidian sources, Quaternary International, 422, 81-92.

Craig, N., Speakman, R. J., Popelka-Filcoff, R. S., Glascock, M. D., Robertson, J. D., Shackley, M. S., and Aldenderfer, M. S., 2007, Comparison of XRF and PXRF for analysis of archaeological obsidian from southern Perú, Journal of Archaeological Science, 34(12), 2012-24.

De Silva, S., 1989, Altiplano-Puna volcanic complex of the central Andes, Geology, 17(12), 1102-6.

De Souza, P., Sinclaire, C., Molina, R., and Gallardo, F., 2002, Una nota sobre obsidianas de una fuente secundaria en la Quebrada Pelún (localidad de Machuca, San Pedro de Atacama), Boletín de la Sociedad Chilena de Arqueología, 33-4, 81-3.

Dillehay, T. D., 2008, Profiles in Pleistocene history, in Handbook of South American archaeology (eds. H. Silverman and W. H. Isbell), 29-77, Springer, New York.

Duke, C., and Steele, J., 2010, Geology and lithic procurement in Upper Palaeolithic Europe: a weights-of-evidence based GIS model of lithic resource potential, Journal of Archaeological Science, 37(4), 813-24. 
Ebert, C. E., Dennison, M., Hirth, K. G., McClure, S. B., and Kennett, D. J., 2015, Formative period obsidian exchange along the Pacific Coast of Mesoamerica, Archaeometry, 57, 54-73.

Escola, P. S., Hocsman, S., and Babot, M. P., 2016, Moving obsidian: the case of Antofagasta de la Sierra basin (southern Argentinean Puna) during the late Middle and Late Holocene, Quaternary International, 422, 109-22.

Flegenheimer, N., and Weitzel, C., 2017, Fishtail points from the Pampas of South America: their variability and life histories, Journal of Anthropological Archaeology, 45, 142-56.

Frahm, E., 2016, Can I get chips with that? Sourcing small obsidian artifacts down to microdebitage scales with portable XRF, Journal of Archaeological Science: Reports, 9, 448-67.

Franco, N. V., Cirigliano, N. A., Vetrisano, L., and Ambrústolo, P., 2015, Raw material circulation at broad scales in southern Patagonia (Argentina): the cases of the Chico and Santa Cruz River basins, Quaternary International, 375, 72-83.

Freund, K. P., 2013, An assessment of the current applications and future directions of obsidian sourcing studies in archaeological research, Archaeometry, 55, 779-93.

Giesso, M., 2003, Stone tool production in the Tiwanaku heartland, in Tiwanaku and its hinterland: archaeology and paleoecology of an Andean civilization (ed. A. L. Kolata), 363-83, Smithsonian Institution Press, Washington, DC.

Giesso, M., Durán, Neme, G., Glascock, M. D., Cortegoso, V., Gil, A., and Sanhueza, L., 2011, A study of obsidian source usage in the central Andes of Argentina and Chile, Archaeometry, 53, 1-21.

Glascock, M. D., 2010, Comparison and contrast between XRF and NAA: used for characterization of obsidian sources in central Mexico, in X-ray fluorescence spectrometry (XRF) in geoarchaeology (ed. M. S. Shackley), 161-92, Springer, New York.

Glascock, M. D., and Ferguson, J. R., 2012, Report on the analysis of obsidian source samples by multiple analytical methods, Report on file at the University of Missouri Research Reactor, Columbia, MO.

Glascock, M. D., and Giesso, M., 2012, New perspectives on obsidian procurement and exchange at Tiwanaku, Bolivia, in Obsidian and ancient manufactured glasses (eds. I. Liritzis and C. M. Stevenson), 86-96, University of New Mexico Press, Albuquerque, NM.

Glascock, M. D., and Neff, H., 2003, Neutron activation analysis and provenance research in archaeology, Measurement Science and Technology, 14(9), 1516-26.

Glascock, M. D., Speakman, R. J., and Burger, R. L., 2007, Sources of archaeological obsidian in Peru: descriptions and geochemistry, in Archaeological chemistry: analytical techniques and archaeological interpretation (eds. M. D. Glascock, R. J. Speakman, and R. S. Popelka-Filcoff), American Chemical Society, Washington, DC.

Goebel, T., Waters, M. R., and O'Rourke, D. H., 2008, The late Pleistocene dispersal of modern humans in the Americas, Science, 319(5869), 1497-502.

Gould, R. A., and Saggers, S., 1985, Lithic procurement in central Australia: a closer look at Binford's idea of embeddedness in archaeology, American Antiquity, 50(1), 117-36.

Grosjean, M., Núñez, L., and Cartajena, I., 2005, Palaeoindian occupation of the Atacama Desert, northern Chile, Journal of Quaternary Science, 20(7-8), 643-53.

Hazelwood, L., and Steele, J., 2004, Spatial dynamics of human dispersals: constraints on modelling and archaeological validation, Journal of Archaeological Science, 31(6), 669-79.

Jennings, J., and Glascock, M. D., 2002, Description and method of exploitation of the Alca obsidian source, Peru, Latin American Antiquity, 13(1), 107-18.

Kellett, L. C., Golitko, M., and Bauer, B. S., 2013, A provenance study of archaeological obsidian from the Andahuaylas region of southern Peru, Journal of Archaeological Science, 40(4), 1890-902.

Kelly, R. L., 1988, The three sides of a biface, American Antiquity, 53(4), 717-34.

Kelly, R. L., and Todd, L. C., 1988, Coming into the country: early Paleoindian hunting and mobility, American Antiquity, 53(2), 231-44.

Kuhn, S. L., 1992, On planning and curated technologies in the Middle Paleolithic, Journal of Anthropological Research, 48(3), 185-214

Latorre, C., Santoro, C. M., Ugalde, P. C., Gayo, E. M., Osorio, D., Salas-Egana, C., De Pol-Holz, R., Joly, D., and Rech, J. A., 2013, Late Pleistocene human occupation of the hyperarid core in the Atacama Desert, northern Chile, Quaternary Science Reviews, 77, 19-30.

Madsen, D. B., 2015, A framework for the initial occupation of the Americas, PaleoAmerica, 1(3), 217-50.

Meltzer, D. J., 2009, First peoples in a New World: colonizing ice age America, University of California Press, Berkeley, CA.

Meltzer, D. J., 2015, Pleistocene overkill and North American mammalian extinctions, Annual Review of Anthropology, 44, 33-53. 
Méndez, C., 2015, Los primeros andinos: tecnología lítica de los habitantes del centro de Chile trece mil años atrás, Fondo editorial, Pontificia Universidad Católica del Perú, Lima.

Méndez, C. A., Stern, C. R., Reyes, O. R., and Mena, F., 2012, Transporte de larga distancia de obsidianas en Patagonia centro-sur durante el Holoceno temprano, Chungara, Revista de Antropología Chilena, 44(3), 363-75.

Morales, M. S., Nielsen, A. E., and Villalba, R., 2013, First dendroarchaeological dates of prehistoric contexts in South America: chullpas in the Central Andes, Journal of Archaeological Science, 40(5), 2393-401.

Nelson, M. C., 1991, The study of technological organization, Archaeological Method and Theory, 3, 57-100.

Nielsen, A. E., 2004, Aproximación a la arqueología de la frontera tripartita Bolivia-Chile-Argentina, Chungara, Revista de Antropología Chilena, 36(Suppl. Esp. 2), 861-78.

Nielsen, A. E., Vázquez, M. M., Avalos, J. C., and Angiorama, C. I., 2000, Prospecciones arqueológicas en la Reserva 'Eduardo Avaroa' (Sud Lípez, Dpto. Potosí, Bolivia), Textos Antropológicos, 11, 89-112.

Nielsen, A. E., Mercolli, P. H., and Nasif, N., 2010, Ocupaciones temporarias y explotación faunística en la región lacustre altoandina, in Actas del XVII Congreso Nacional de Arqueología Chilena, 1365-78, Sociedad Chilena de Arqueología, Valdivia.

Núñez, L., Grosjean, M., and Cartajena, I., 2002, Human occupations and climate change in the Puna de Atacama, Chile, Science, 298(5594), 821-4.

Osorio, D., Capriles, J. M., Ugalde, P. C., Herrera, K. A., Sepúlveda, M., Gayo, E. M., Latorre, C., Jackson, D., De PolHolz, R., and Santoro, C. M., 2017, Hunter-gatherer mobility strategies in the high Andes of northern Chile during the late Pleistocene-Early Holocene transition (ca. 11,500-9500 cal b.p.), Journal of Field Archaeology, 42(3), $228-40$.

Pacheco, J., and Ramírez, V., 1997, Mapa geológico de Cañapa/Alota Hoja 5929/6029, in Carta geológica de Bolivia, Publicación SGM Serie I-CGB-45, scale 1:100,000, 1 sheet, Servicio Nacional de Geología y Minería, La Paz.

Pintar, E., Martínez, J. G., Aschero, C. A., and Glascock, M. D., 2016, Obsidian use and mobility during the Early and Middle Holocene in the Salt Puna, NW Argentina, Quaternary International, 422, 93-108.

Placzek, C., Quade, J., and Patchett, P. J., 2006, Geochronology and stratigraphy of late Pleistocene lake cycles on the southern Bolivian Altiplano: implications for causes of tropical climate change, Geological Society of America Bulletin, 118(5-6), 515-32.

Placzek, C. J., Quade, J., and Patchett, P. J., 2013, A 130 ka reconstruction of rainfall on the Bolivian Altiplano, Earth and Planetary Science Letters, 363, 97-108.

Politis, G. G., Gutiérrez, M. A., Rafuse, D. J., and Blasi, A., 2016, The arrival of Homo sapiens into the southern cone at 14,000 years ago, PLoS One, 11(9), e0162870.

Rademaker, K., Glascock, M. D., Kaiser, B., Gibson, D., Lux, D. R., and Yates, M. G., 2013, Multi-technique geochemical characterization of the Alca obsidian source, Peruvian Andes, Geology, 41(7), 779-82.

Salgán, L., Garvey, R., Neme, G., Gil, A., Giesso, M., Glascock, M. D., and Durán, V., 2015, Las Cargas: characterization and prehistoric use of a southern Andean obsidian source, Geoarchaeology, 30(2), 139-50.

Salisbury, M. J., Jicha, B. R., de Silva, S. L., Singer, B. S., Jiménez, N. C., and Ort, M. H., $2010,{ }^{40} \mathrm{Ar} /{ }^{39} \mathrm{Ar}$ chronostratigraphy of Altiplano-Puna volcanic complex ignimbrites reveals the development of a major magmatic province, Geological Society of America Bulletin, 123(5-6), 821-40.

Santoro, C. M., Capriles, J. M., Gayo, E. M., de Porras, M. E., Maldonado, A., Standen, V. G., Latorre, C., Castro, V., Angelo, D., McRostie, V., Uribe, M., Valenzuela, D., Ugalde, P. C., and Marquet, P. A., 2017, Continuities and discontinuities in the socio-environmental systems of the Atacama Desert during the last 13,000 years, Journal of Anthropological Archaeology, https://doi.org/10.1016/j.jaa.2016.08.006.

Seelenfreund, A., Rees, C., Bird, R., Bailey, G., Barcena, R., and Duran, V., 1996, Trace-element analysis of obsidian sources and artifacts of central Chile (Maule River Basin) and western Argentina (Colorado River), Latin American Antiquity, 7(1), 7-20.

Seelenfreund, A., Pino, M., Glascock, M. D., Sinclaire, C., Miranda, P., Pasten, D., Cancino, S., Dinator, M. I., and Morales, J. R., 2010a, Morphological and geochemical analysis of the Laguna Blanca/Zapaleri obsidian source in the Atacama Puna, Geoarchaeology, 25(2), 245-63.

Seelenfreund, A., Sinclaire, C., Dinator, M. I., Morales, J. R., Pasten, D., Miranda, P., Cancino, S., Lera, L., and Rees, C., 2010b, Negras y brillantes: explotación y distribución de obsidianas en la macro región del Salar de Atacama, in Actas del XVII Congreso Nacional de Arqueología Chilena, 811-24, Sociedad Chilena de Arqueología, Valdivia.

Seeman, M. F., 1994, Intercluster lithic patterning at Nobles Pond: a case for 'disembedded' procurement among early Paleoindian societies, American Antiquity, 59(2), 273-88.

Shackley, M. S., 1998, Intrasource chemical variability and secondary depositional processes: lessons from the American southwest, in Archaeological obsidian studies: method and theory (ed. M. S. Shackley), 83-102, Plenum Press, New York. 
Shackley, M. S., 2005, Obsidian: geology and archaeology in the North American Southwest, University of Arizona Press, Tucson, AZ.

Soler, M. M., Caffe, P. J., Coira, B. L., Onoe, A. T., and Mahlburg Kay, S., 2007, Geology of the Vilama caldera: a new interpretation of a large-scale explosive event in the Central Andean plateau during the Upper Miocene, Journal of Volcanology and Geothermal Research, 164(1), 27-53.

Speth, J. D., Newlander, K., White, A. A., Lemke, A. K., and Anderson, L. E., 2013, Early Paleoindian big-game hunting in North America: provisioning or politics? Quaternary International, 285, 111-39.

Suárez, R., 2011, Movilidad, acceso y uso de agata traslúcida por los cazadores-recolectores tempranos durante la transición Pleistoceno-Holoceno en el norte de Uruguay (ca. 11,000-8500 a.p.), Latin American Antiquity, 22(3), 359-84.

Surovell, T. A., 2000, Early Paleoindian women, children, mobility, and fertility, American Antiquity, 65(3), $493-508$.

Surovell, T. A., 2009, Toward a behavioral ecology of lithic technology: cases from Paleoindian archaeology, University of Arizona Press, Tucson, AZ.

Tomka, S. A., 2001a, An ethnoarchaeological study of tool design and selection in an Andean agro-pastoral context, Latin American Antiquity, 12(4), 395-411.

Tomka, S. A., 2001b, 'Up and down we move ...': factors conditioning agro-pastoral settlement organization in mountainous settings, in Ethnoarchaeology of Andean South America: contributions to archaeological method and theory (ed. L. A. Kuznar), 138-62, International Monographs in Prehistory, Ann Arbor, MI.

Tripcevich, N., 2007, Quarries, caravans, and routes to complexity: prehispanic obsidian in the south-central Andes, Ph.D. dissertation, University of California, Santa Barbara, Santa Barbara, CA.

Tripcevich, N., and Contreras, D. A., 2013, Archaeological approaches to obsidian quarries: investigations at the Quispisisa source, in Mining and quarrying in the ancient Andes: socipolitical, economic, and symbolic dimensions (eds. N. Tripcevich and K. J. Vaughn), 23-44, Springer, New York.

Tripcevich, N., and Contreras, D. A., 2011, Quarrying evidence at the Quispisisa obsidian source, Ayacucho, Peru, Latin American Antiquity, 22(1), 121-36.

Tripcevich, N., and Mackay, A., 2011, Procurement at the Chivay obsidian source, Arequipa, Peru, World Archaeology, 43(2), 271-97.

Tripcevich, N., and Mackay, A., 2012, Spatial and temporal variation in stone raw material provisioning in the Chivay obsidian source area, in Advances in Titicaca Basin archaeology, vol. 3 (eds. A. Vranich, E. A. Klarich, and C. Stanish), 141-62, University of Michigan Press, Ann Arbor, MI.

Williams, P. R., Dussubieux, L., and Nash, D. J., 2012, Provenance of Peruvian Wari obsidian: comparing INAA, LAICP-MS, and portable XRF, in Obsidian and ancient manufactured glasses (eds. I. Liritzis and C. M. Stevenson), 75-85, University of New Mexico Press, Albuquerque, NM.

Yacobaccio, H. D., 2012, Intercambio y caravanas de llamas en el Sur Andino (3000-1000 AP), Comechingonia, 16(1), 31-51.

Yacobaccio, H. D., Escola, P. S., Lazzari, M., and Pereyra, F. X., 2002, Long-distance obsidian traffic in northwestern Argentina, in Geological evidence of long-distance exchange (ed. M. D. Glascock), 167-204, Bergin \& Garvey, Westport, CT.

Yacobaccio, H. D., Escola, P. S., Pereyra, F. X., Lazzari, M., and Glascock, M. D., 2004, Quest for ancient routes: obsidian sourcing research in Northwestern Argentina, Journal of Archaeological Science, 31(2), 193-204.

\section{SUPPORTING INFORMATION}

Additional Supporting Information may be found online in the supporting information tab for this article.

Table S1. INAA results of source and archaeological specimenens analyzed in this study. Table S2. ED-XRF results of source and archaeological specimens analyzed in this study. 